Japanese Journal of Physiology, 30, 671-687, 1980

\title{
Temperature Coefficient of and Oxygen Effect on the Antimony Microelectrode
}

\author{
Noriko SAtake, Yutaka Matsumura, and Mamoru Fujimoto \\ Department of Physiology, Osaka Medical College, \\ Takatsuki, Osaka, 569 Japan
}

\begin{abstract}
With regard to $\mathrm{pH}$ measurement of biological fluids in vivo with metal-metal oxide microelectrodes, the effect of temperature and partial pressure of oxygen on antimony $(\mathrm{Sb})$ microelectrodes was examined, and $\mathrm{pH}$ of blood was estimated in the bullfrog.

The temperature coefficient $(d E / d t)$ of electromotive force (EMF) of Sb-microelectrodes in the range of 7 to $37^{\circ} \mathrm{C}$ was $-1.18 \pm 0.113 \mathrm{mV} /{ }^{\circ} \mathrm{C}$ (mean $\pm \mathrm{SEM}$ ) in Ringer solution, whereas that of the $\mathrm{pH}$ glass electrode in the same solution was $-0.43 \pm 0.035 \mathrm{mV} /{ }^{\circ} \mathrm{C}$. When estimated in Tris buffer solution, it was $-0.06 \pm 0.063 \mathrm{mV} /{ }^{\circ} \mathrm{C}$ for $\mathrm{Sb}$-microelectrodes and $1.05 \pm 0.036 \mathrm{mV} /{ }^{\circ} \mathrm{C}$ for glass electrodes.

The change of slope constant $(\alpha$ in $-\mathrm{mV} / \mathrm{pH})$ in the Sb-microelectrode due to temperature change could be predicted empirically from: $\alpha=0.40$ $(t-25)+55.3$, where $t$ represents the measuring temperature in ${ }^{\circ} \mathrm{C}$.

The resultant deviation of $\mathrm{pH}$ readings between $\mathrm{Sb}$ and glass electrodes, $\Delta \mathrm{pH}_{\mathrm{Sb}-\mathrm{Glass}}$, may be expressed by:

$$
\Delta \mathrm{pH}_{\mathrm{Sb}-\mathrm{G} 1 \mathrm{ass}}=0.00183(t-25)+0.016 \text {. }
$$

In the range of 45 to $760 \mathrm{mmHg}$ of oxygen partial pressure at fixed $\mathrm{pH}$, the EMF increased linearly with the increase of $P_{\mathrm{O}_{2}}$, the slope $\left(d E / d \log \left(P_{\mathrm{O}_{2}}\right)\right)$ being $11.7 \pm 0.42$ (SEM) $\mathrm{mV}\left(n=13, t=25^{\circ} \mathrm{C}\right)$.

In consideration of the above effects, the blood $\mathrm{pH}$ of bullfrog was estimated to be $7.697 \pm 0.092$ (SD) and $7.729 \pm 0.111$ with glass and $\mathrm{Sb}$-microelectrodes respectively, the difference between the two being relatively minor.
\end{abstract}

Application of the antimony (Sb) microelectrode for renal micropuncture study was first attempted by VIEIRA and MALNIC (1968). Since then, a number of investigators have carried out the experiment for studying the mechanism of hydrogen ion transport across the tubular borders (MALNIC et al., 1972; KARLMARK and DANIELSON, 1974; GreEN and GIEBISCH, 1975; SoHTELl and KARLMARK 1976; KOTERA et al., 1977), but the detailed electrochemical behavior of the antimony

Received for Publication October 11, 1979

佐竹典子, 松村 裕, 藤本 守 
electrode is not yet fully understood, numerous conflicting data existing concerning the disturbances of their electrical potential by various physicochemical parameters (Green and Giebisch, 1974; Puschett and Zurbach, 1974). Perley (1939) and STосK et al. (1958) pointed out that the change of temperature would have a considerable effect on the $\mathrm{pH}$ reading of the antimony electrode, its temperature coefficient varying with the $\mathrm{pH}$ and type of buffer used and reference electrode in the system. However, details remained obscure as to whether the temperature affects the electromotive force of the electrode system or sensitivity of the $\mathrm{pH}$ electrode. In view of the fact that the electrode shows a great deal of instability, we have to establish a method of measurement with the least trouble in stability of $\mathrm{pH}$ reading.

Concerning the influence of partial pressure of oxygen, several authors have reported that the potential of the Sb-electrode varied with the concentration of dissolved oxygen (Kauko and KNAPPSBerg, 1939; Tourky and Moussa, 1948; El WaKkad, 1950). Vieira and Malnic (1968) examined the effect of oxygen on $\mathrm{pH}$ readings of pre-equilibrated buffers between $\mathrm{pH} 5.05$ and 7.54 at $37^{\circ} \mathrm{C}$ with the $P_{\mathrm{O}_{2}}$ ranging from 35 to $138 \mathrm{mmHg}$, and they showed that no significant effect was observed with changes in oxygen tensions. On the other hand, in a recent report by QUEHENBERGER (1977), a considerably large value of $d E / d \log \left(P_{\mathrm{O}_{2}}\right), 58.5$ $\mathrm{mV}$, under conditions of constant $\mathrm{pH}(=7.1)$ and $P_{\mathrm{CO}_{2}}(=33.2 \mathrm{mmHg})$ has been described. Accordingly, we need to reconsider the effect of oxygen, as well as of temperature, on the Sb-microelectrode and examine the practical applicability of this electrode to the $\mathrm{pH}$ measurement of biological fluid, such as blood. This report deals with the above problem. The protein effect on the Sb-electrode will be discussed in a subsequent report (SATAKE et al., 1980).

\section{METHODS}

1) $p H$-Electrodes. The antimony microelectrode (Sb-microelectrode) was manufactured by the method reported previously (Fujimoto et al., 1980). The tip of the microelectrode was ground to about $2-5 \mu \mathrm{m}$ in diameter, and it was calibrated with Tris buffer and frog Ringer bicarbonate solution. The details of its calibration have been described elsewhere (MATSUMura et al., 1980). Since it is known that the Sb-electrode is susceptible to the effects of various buffers, especially phosphate and citrate buffers (YoshimURA, 1936; GrEEN and GieBISCH, 1974) these solutions may not be used for the calibration of the Sb-electrode. In search of the most suitable buffer for this purpose, we concluded that Tris was the most appropriate among the various buffers tested. The possible effect of ionic strength on the Sb-electrode (the "salt effect") was also discussed in the preceding paper (MATSUMuRA et al., 1980), where it was shown that, in the practical use of the $\mathrm{Sb}$-microelectrode, special care must be taken regarding the following points: (1) For electrode calibration, Tris buffer solution should be 
used, (2) Phosphate concentration should be maintained constant during all measurements, and (3) The ionic strength of samples should be the same as those of calibration solutions. The electrodes with slope constants of more than -50 $\mathrm{mV} / \mathrm{pH}$ and $\Delta \mathrm{pH}_{\mathrm{Sb}-\mathrm{Glass}}$ of less than 0.02 units, calibrated with frog Ringer solution, were used for the present study. The $\mathrm{pH}$ glass electrode used for the general test was a commercial electrode of an immersion type (Toa HG-2005) and that for the blood $\mathrm{pH}$ measurement was a syringe type (Toa HG-5005).

The electrical measurements were carried out with an electrometer (Keithley $610 \mathrm{C}$ ) and digital $\mathrm{pH}$ meter (Toa HM-15A) at room temperature $\left(20 \pm 2.5^{\circ} \mathrm{C}\right.$ ), where a saturated calomel electrode (Toa HC-305D) was used as the reference half-cell.

2) Measurement of temperature and $P_{\mathrm{O}_{2}}$ effect. Effects of change in temperature and partial pressure of oxygen $\left(P_{\mathrm{O}_{2}}\right)$ on the electromotive force (EMF) of $\mathrm{Sb}$-microelectrodes were examined with the apparatus shown in Fig. 1.

The temperature of the total assembly of the electrode system including $\mathrm{pH}$ and reference electrodes was maintained constant over the range of 7 to $37^{\circ} \mathrm{C}$ by a thermoregulator with external circulation (Yamato, Coolnics). The chamber containing the sample was placed on a heat-insulating plate over a magnetic stirrer and the sample was stirred with this "cool-mixer" while monitoring with a thermistor. The Sb-microelectrode or glass electrode was inserted into the sample from the top of the chamber. A reference calomel electrode using $3 \mathrm{M} \mathrm{KCl}$ solution was connected with the sample through a $3 \mathrm{M} \mathrm{KCl}$ agar bridge. Tris

Apparatus for temperature and $\mathrm{PO}_{2}$ calibration of Sb-microelectrode

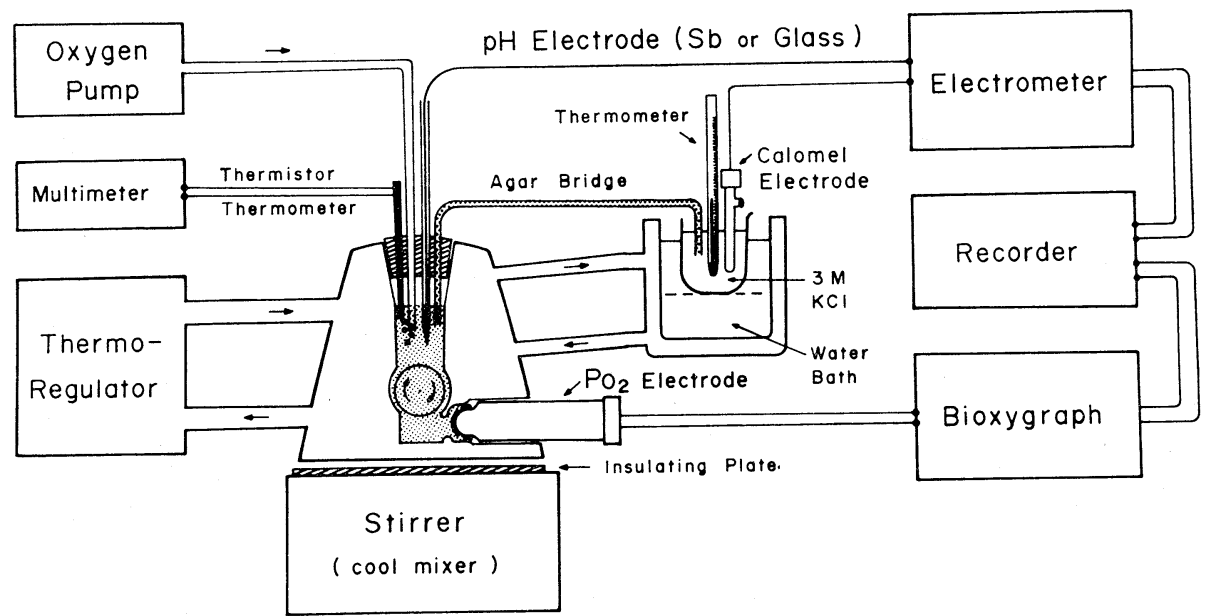

Fig. 1. Experimental apparatus for measuring the effects of temperature and partial pressure of oxygen $\left(P_{\mathrm{O}_{2}}\right)$ on the electromotive force (EMF) of Sb-microelectrode.

Vol. 30, No. 5, 1980 
Table 1. Composition of test solutions for the experiments of temperature and $P_{\mathrm{O}_{2}}$ effect.

\begin{tabular}{ccc}
\hline & $\begin{array}{c}\text { Tris buffer } \\
\text { solution }\end{array}$ & $\begin{array}{c}\text { Frog Ringer } \\
\text { bicarbonate }\end{array}$ \\
\hline $\mathrm{NaCl}$ & 2.0 & 92.0 \\
$\mathrm{CaCl}$ & 1.8 & 1.8 \\
$\mathrm{KCl}$ & 3.5 & 3.5 \\
$\mathrm{MgSO}_{4}$ & 1.2 & 1.2 \\
$\mathrm{Na}_{2} \mathrm{HPO}_{4}$ & 1.58 & 1.58 \\
$\mathrm{NaH}_{2} \mathrm{PO}_{4}$ & 0.5 & 0.5 \\
$\mathrm{NaHCO}_{3}$ & 15.6 & 15.6 \\
Tris & 90.0 & - \\
\hline$I$ & 0.127 & 0.127 \\
(Ionic strength) & 217 & 217 \\
\hline Osmolality & & \\
(mOsm/kg) & & \\
\hline
\end{tabular}

Values of electrolytes are shown in mM. The Tris buffer solution has the same composition as frog Ringer solution except for the substitution Tris for $\mathrm{NaCl}$. Ionic strength and osmolality are the same.

buffer and Ringer bicarbonate (RB) solution were used for the test samples. Their compositions are shown in Table 1.

In the observation of $P_{\mathrm{O}_{2}}$ change, the test solutions were kept stirred at a fixed temperature of $25^{\circ} \mathrm{C}$ and the $P_{\mathrm{O}_{2}}$ was controlled by a continuous supply of oxygen gas with an oxygen pump. The $P_{\mathrm{O}_{2}}$ was measured with an oxymeter (Kyusui Chemical Institute, Bioxygraph) using a $P_{\mathrm{O}_{2}}$ electrode which was inserted into the sample near the bottom thereof.

3) Blood pH measurement of bullfrog (Rana catesbeiana). Arterial blood was collected from a large abdominal vessel or the aorta with a heparinized syringe under anaerobic conditions, and transferred into a $10 \mathrm{ml}$ beaker under mineral oil. The measurement of blood $\mathrm{pH}$ was performed both with the Sb-microelectrode and glass electrode simultaneously at room temperature.

\section{RESULTS}

\section{1) The change of EMF at different temperatures}

The change of electromotive force (EMF) of Sb-micro and glass electrodes was examined over the range of 7 to $37^{\circ} \mathrm{C}$. The result is shown in Fig. 2. The magnitude in EMF change from the value at $25^{\circ} \mathrm{C}$ was plotted against the temperature in ${ }^{\circ} \mathrm{C}$. The upper panel shows the data using Tris buffer solution. The open circles $(\bigcirc)$ are those from solution of pH 7.2 and the open triangles $(\triangle)$ those from solution of $\mathrm{pH}$ 7.8. The values were presented as mean \pm SEM of 9 samples. It was found that in the Sb-microelectrodes calibrated with Tris buffer the change of EMF was relatively minor, whereas in the glass electrode the EMF increased 

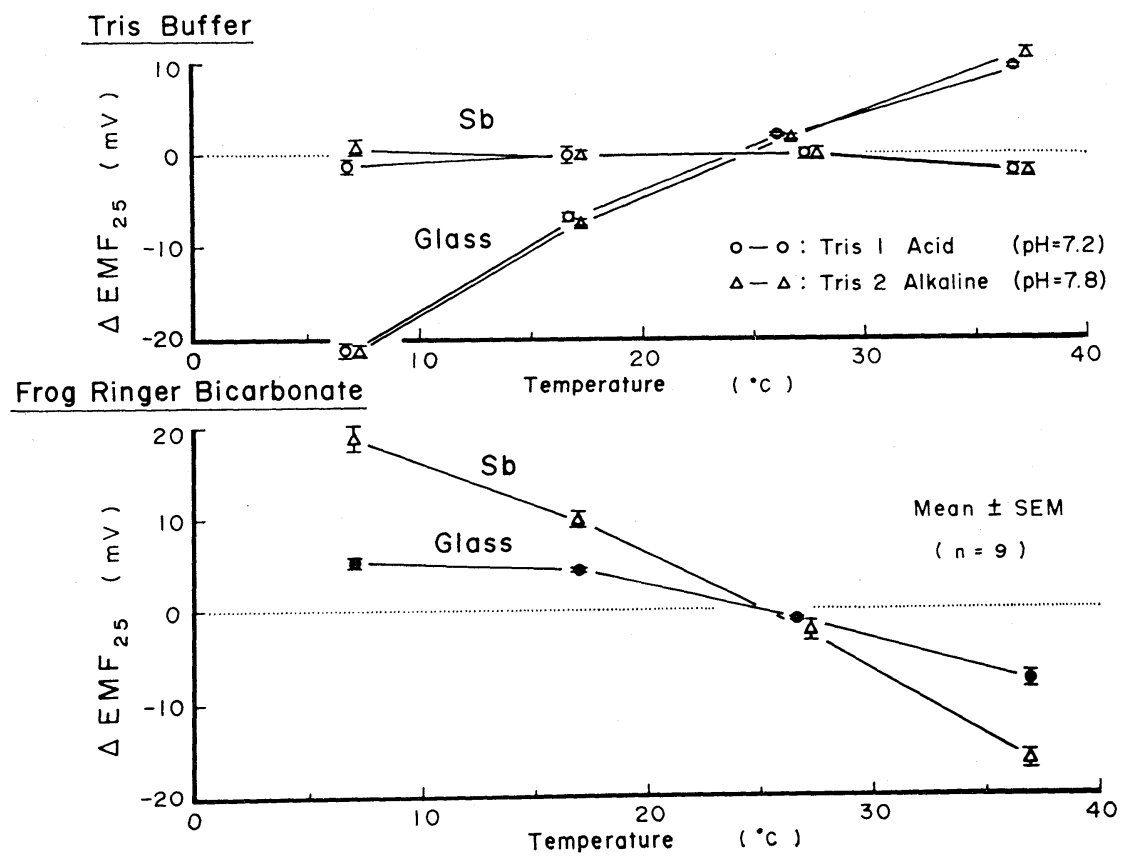

Fig. 2. Effect of temperature on the EMF of Sb-micro and glass electrodes in Tris buffer and frog Ringer bicarbonate solutions. Changes of EMF from the value at $25^{\circ} \mathrm{C}$ are plotted against temperature in ${ }^{\circ} \mathrm{C}$.

Table 2. Temperature coefficients of EMF $(d E / d t)$ in $\mathrm{pH}$ measurement by Sb-micro and glass electrodes in both Tris buffer and frog Ringer solutions.

\begin{tabular}{cccccc}
\hline & & \multicolumn{3}{c}{ Temperature $\left({ }^{\circ} \mathrm{C}\right)$} & $\begin{array}{c}\text { Total } \\
\text { range }\end{array}$ \\
\cline { 3 - 5 } & & $7-17$ & $12-27$ & $27-37$ & \\
\hline \multirow{3}{*}{ Sb-microelectrode } & Tris buffer & 0.02 & 0.01 & -0.02 & -0.06 \\
& & \pm 0.075 & \pm 0.059 & \pm 0.055 & \pm 0.063 \\
& Frog Ringer & -0.91 & -1.21 & -1.41 & -1.18 \\
& & \pm 0.116 & \pm 0.106 & \pm 0.118 & \pm 0.113 \\
Glass electrode & Tris buffer & 1.42 & 0.91 & 0.84 & 1.05 \\
& & \pm 0.055 & \pm 0.022 & \pm 0.028 & \pm 0.036 \\
& \multirow{2}{*}{ Frog Ringer } & -0.08 & -0.56 & -0.65 & -0.43 \\
& & \pm 0.037 & \pm 0.017 & \pm 0.050 & \pm 0.035 \\
\hline
\end{tabular}

Values are presented in $\mathrm{mV} /{ }^{\circ} \mathrm{C}$ as mean $\pm \mathrm{SEM}$ of 9 examples. Note that the temperature coefficient was negligibly small (i.e., $-0.06 \pm 0.063 \mathrm{mV} /{ }^{\circ} \mathrm{C}$ ) for $\mathrm{Sb}$-microelectrodes in Tris buffer solution.

almost linearly with the increase of temperature. The lower panel shows the data from frog Ringer bicarbonate solution. The solid circles $(\bullet)$ are the data of the glass electrode, while the solid triangles (A) are those of the Sb-micro- 
electrode. The degree of EMF change decreased with the increase of temperature in both electrodes, but the slope of Sb-microelectrodes was larger than that of glass electrodes.

Temperature coefficient of EMF. The temperature coefficient $(d E / d t)$ of EMF for both electrodes was calculated in the range of 7 to $37^{\circ} \mathrm{C}$, the data being listed in Table 2. The values were presented in $\mathrm{mV} /{ }^{\circ} \mathrm{C}$ as mean $\pm \mathrm{SEM}$ of 9 samples. The temperature coefficient was $-1.18 \pm 0.113 \mathrm{mV} /{ }^{\circ} \mathrm{C}$ for $\mathrm{Sb}$-microelectrodes in Ringer solution, and $-0.43 \pm 0.035 \mathrm{mV} /{ }^{\circ} \mathrm{C}$ for glass electrodes. When estimated in Tris buffer solution, however, it was $-0.06 \pm 0.063 \mathrm{mV} /{ }^{\circ} \mathrm{C}$ for Sb-microelectrodes and $1.05 \pm 0.036 \mathrm{mV} /{ }^{\circ} \mathrm{C}$ for glass electrodes.

\section{2) The change of slope constant due to temperature change}

The temperature may affect not only the EMF, but also the slope constant or sensitivity to $\mathrm{pH}$ in both $\mathrm{Sb}$-micro and glass electrodes. Figure 3 shows the change of slope constant ( $\alpha$ in $-\mathrm{mV} / \mathrm{pH}$ ) for the Sb-microelectrode due to temperature change. The slope constant of the $\mathrm{Sb}$-microelectrode presented on the vertical axis was related to the temperature $\left({ }^{\circ} \mathrm{C}\right)$ on the abscissa. The values are presented as mean \pm SEM of samples of parenthesized numbers. As is shown in Fig. 3, the slope increased with the increase of temperature. The general trend was shown by a dashed line drawn by eye. The dotted line indicates the theoretical line which is derived from $2.303 R T / F$ (where $R$ is the gas constant, $T$ the absolute

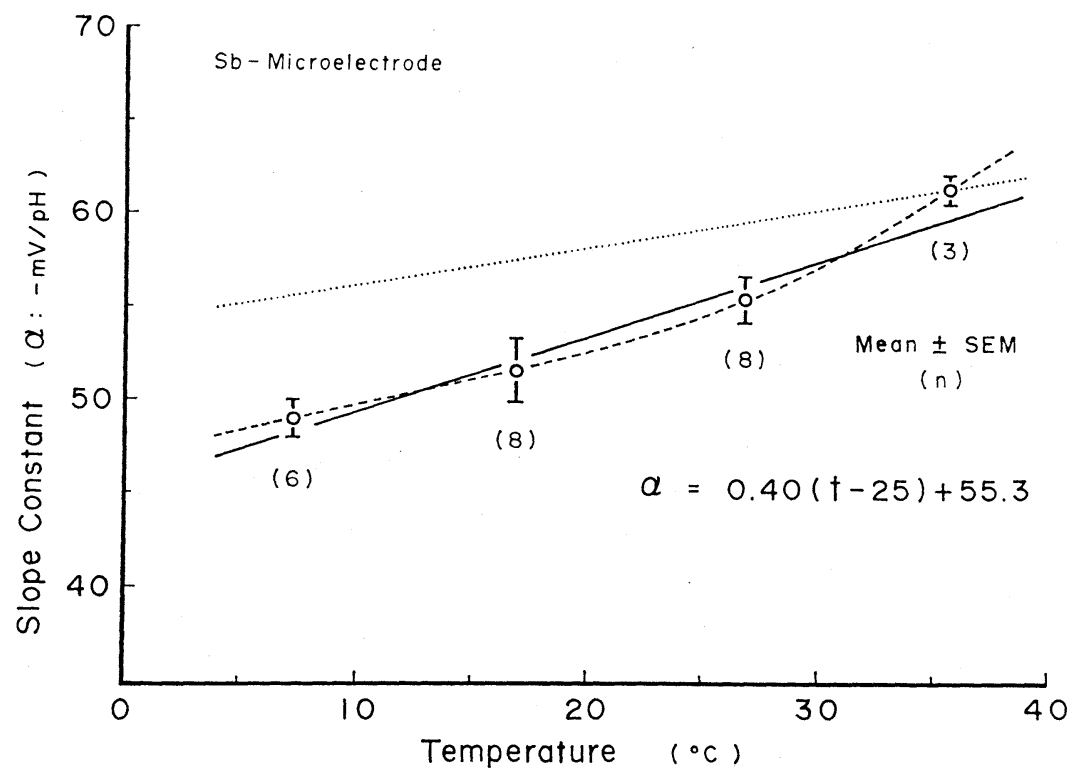

Fig. 3. Change of slope constant $(\alpha$ in $-\mathrm{mV} / \mathrm{pH})$ for the $\mathrm{Sb}$-microelectrode due to temperature change. 


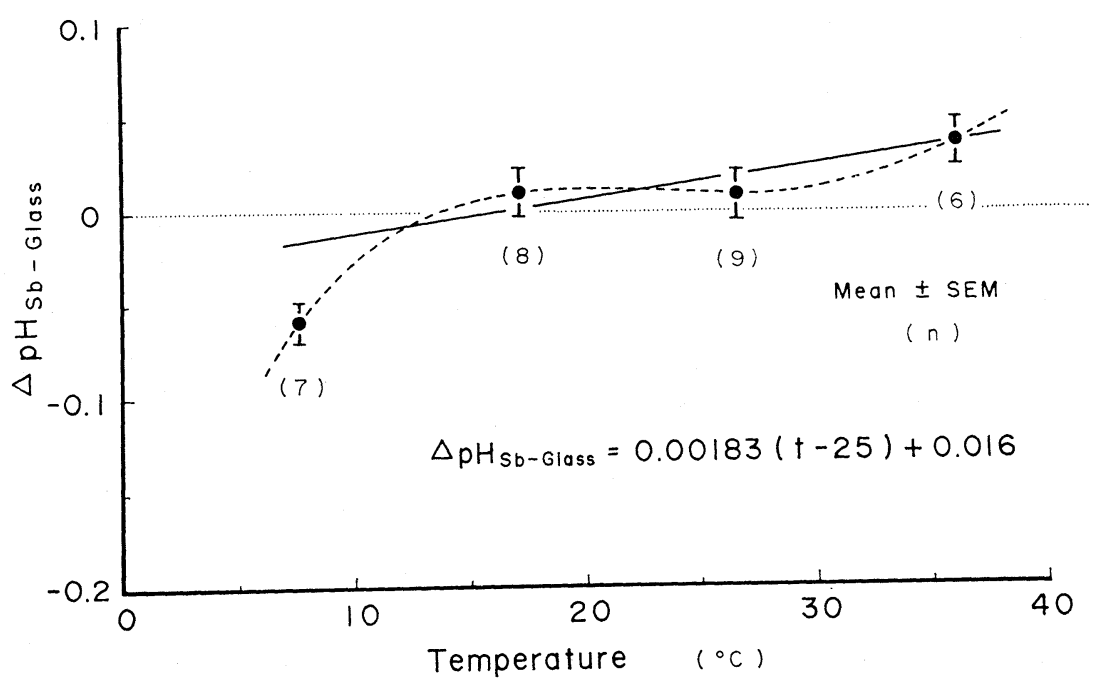

Fig. 4. A temperature-dependent deviation of $\mathrm{pH}$ readings by $\mathrm{Sb}$-microelectrode from glass electrode, $\Delta \mathrm{pH}_{\mathrm{Sb} \text {-G1ass, }}$, produced by a combined effect of temperature on EMF and slope constant.

temperature and $F$ the Faraday constant). The solid line shows the calculated regression line of the observed data, whose correlation coefficient is 0.975 . Thus, one can predict the slope constant for the Sb-microelectrode from the empirical equation, as

$$
\alpha=0.40(t-25)+55.3,
$$

where $t$ represents the measuring temperature in ${ }^{\circ} \mathrm{C}$.

3) The change of $\Delta p H_{\mathrm{Sb}-\mathrm{Glass}}$

Combining the temperature effects on the EMF and slope constant, the deviation of $\mathrm{pH}$ readings between $\mathrm{Sb}$-micro and glass electrode, $\Delta \mathrm{pH}_{\mathrm{Sb} \text {-G1ass }}$, was estimated, the result being shown in Fig. 4. The dashed line gives a general trend and the solid line the regression line, the latter being represented over the range of 7 to $37^{\circ} \mathrm{C}$, as

$$
\Delta \mathrm{pH}_{\mathrm{Sb}-\mathrm{G} 1 \mathrm{ass}}=0.00183(t-25)+0.016
$$

4) $P_{\mathrm{O}_{2}}$ effect

Effect of $P_{\mathrm{O}_{2}}$ on the EMF of the Sb-microelectrode was examined on 13 different microelectrodes, and the data are shown in Fig. 5. The EMF of the Sbmicroelectrode in $\mathrm{mV}$ was plotted against the partial pressure of oxygen in $\mathrm{mmHg}$ on a logarithmic scale. The $\mathrm{pH}$ and temperature of solution were maintained at a constant level in each experiment. As seen in Fig. 5, the EMF log-linearly in- 


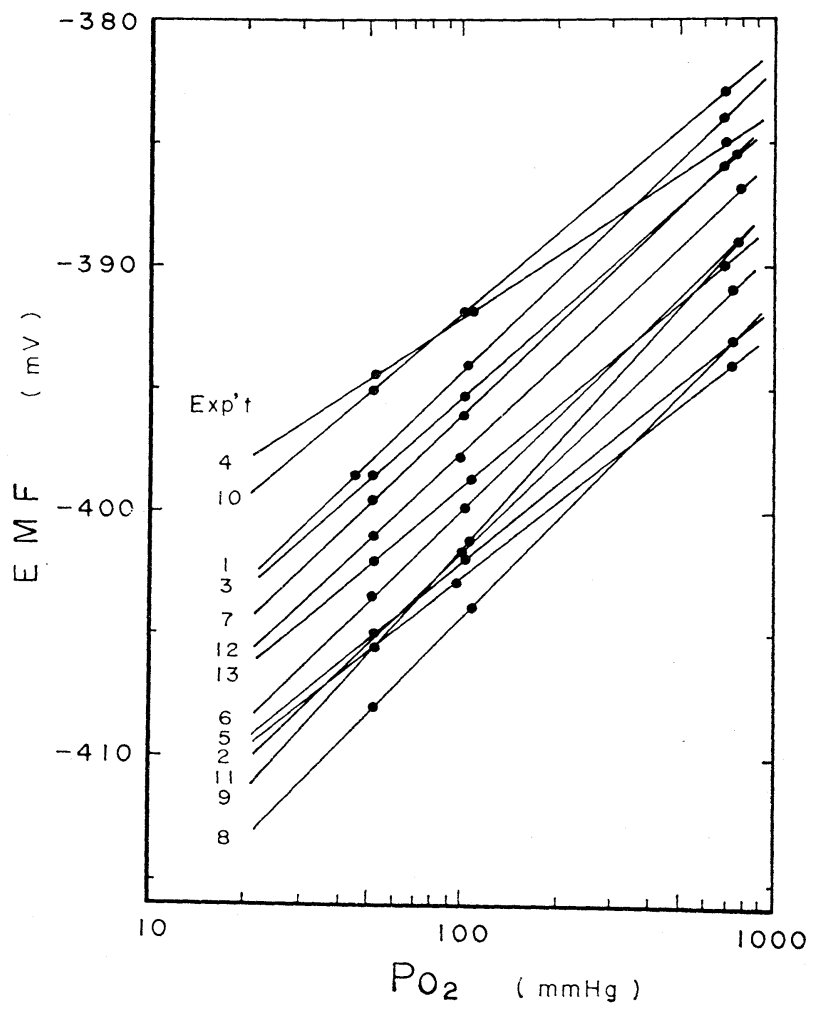

Fig. 5. Effect of oxygen on EMFs of individual Sb-microelectrodes.

Table 3. Ratios of changes in EMF of Sb-microelectrode to oxygen partial pressure.

\begin{tabular}{cc}
\hline Exp't number & $\frac{d E}{d \log \left(P_{\mathrm{O}_{2}}\right)}$ \\
\hline 1 & 12.5 \\
2 & 10.2 \\
3 & 11.4 \\
4 & 8.6 \\
5 & 10.7 \\
6 & 12.7 \\
7 & 12.3 \\
8 & 13.4 \\
9 & 14.4 \\
10 & 10.9 \\
11 & 12.5 \\
12 & 12.2 \\
13 & 10.9 \\
\hline Mean \pm SEM & $11.7 \pm 0.42$ \\
$(n)$ & $(13)$ \\
\hline
\end{tabular}


creased with the increase of $P_{\mathrm{O}_{2}}$ in the range of $c a .45$ to $750 \mathrm{mmHg}$.

The ratio of changes in EMF to oxygen partial pressure was calculated for each electrode, the results being summarized in Table 3 . The measuring temperature was $25^{\circ} \mathrm{C}$. In the range of $c a .45$ to $750 \mathrm{mmHg}$ of $P_{\mathrm{O}_{2}}$, the electrodes showed a response of $d E / d \log \left(P_{\mathrm{O}_{2}}\right)=11.7 \pm 0.42 \mathrm{mV}$ (mean $\pm \mathrm{SEM}, n=13$ ). This value is close to the theoretical value, $14.8 \mathrm{mV}$.

\section{5) pH measurement of bullfrog blood}

Using both Sb-micro and glass electrodes, the blood $\mathrm{pH}$ of bullfrog was measured at $P_{\mathrm{CO}_{2}}$ of $15 \mathrm{mmHg}$ at various temperatures. The results are shown in Fig. 6 and Table 4, indicating that the blood $\mathrm{pH}$ decreased with the increase of temperature. In the former, the solid circles (๑) were the data of the glass electrode, while the open triangles $(\triangle)$ those of the Sb-microelectrode. The mean temperature coefficient for frog blood $\mathrm{pH}$ under our experimental conditions (in temperature range of 21 to $25^{\circ} \mathrm{C}$ ) was calculated to be $-0.0513 /{ }^{\circ} \mathrm{C}$ (correlation coefficient, $r=0.644, p<0.01, n=15$ ) for the glass electrode and $-0.0610 /{ }^{\circ} \mathrm{C}$ $(r=0.641, p<0.01, n=15)$ for the Sb-microelectrode. The mean $\mathrm{pH}$ value of 15 different blood samples was $7.697 \pm 0.092(\mathrm{SD})$ with the $\mathrm{pH}$ glass electrode and $7.741 \pm 0.110$ with the $\mathrm{Sb}$-microelectrode. Therefore, $\Delta \mathrm{pH}_{\mathrm{Sb} \text {-Glass }}$ was $0.044 \pm 0.043$ at the mean temperature of $23.1 \pm 1.2^{\circ} \mathrm{C}$. When corrected for the effect of temperature by the use of the empirical formula (2), it was reduced to $0.032 \pm 0.043$. This would suggest that an accurate frog blood $\mathrm{pH}$ could be estimated by Sbmicroelectrode if the correction for temperature could properly be made.

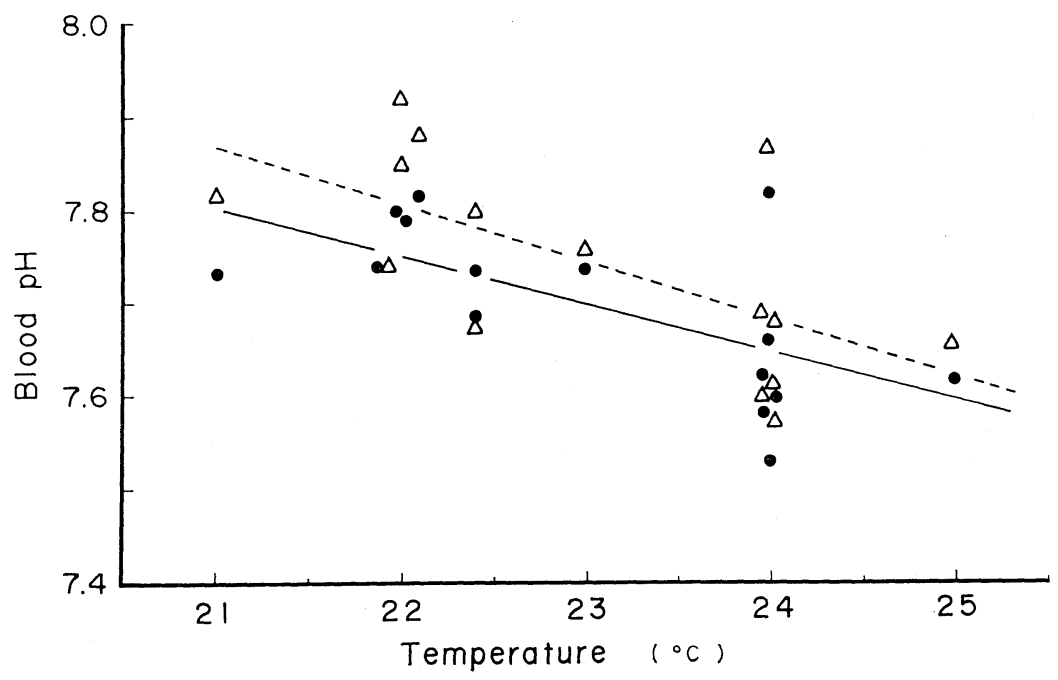

Fig. 6. Relationship between the blood $\mathrm{pH}$ of bullfrog and the measuring temperature. 
Table 4. $\mathrm{pH}$ measurement of bullfrog blood at various temperatures.

\begin{tabular}{|c|c|c|c|c|}
\hline Sample & $\mathrm{pH}_{\mathrm{Glass}}$ & $\begin{array}{c}\text { Temp. } \\
\left({ }^{\circ} \mathrm{C}\right)\end{array}$ & $\Delta \mathrm{pH}_{\mathrm{Sb}-\mathrm{Glass}}$ & $\begin{array}{l}\Delta \mathrm{pH} \text { corrected } \\
\text { for temp. }\end{array}$ \\
\hline 1 & 7.731 & 21.0 & 0.085 & 0.076 \\
\hline 2 & 7.740 & 21.9 & 0.000 & -0.010 \\
\hline 3 & 7.790 & 22.0 & 0.130 & 0.119 \\
\hline 4 & 7.798 & 22.0 & 0.050 & 0.039 \\
\hline 5 & 7.817 & 22.1 & 0.064 & 0.054 \\
\hline 6 & 7.687 & 22.4 & -0.015 & -0.026 \\
\hline 7 & 7.735 & 22.4 & 0.064 & 0.053 \\
\hline 8 & 7.736 & 23.0 & 0.020 & 0.008 \\
\hline 9 & 7.529 & 24.0 & 0.070 & 0.056 \\
\hline 10 & 7.582 & 24.0 & 0.040 & 0.026 \\
\hline 11 & 7.599 & 24.0 & 0.080 & 0.066 \\
\hline 12 & 7.613 & 24.0 & -0.040 & -0.054 \\
\hline 13 & 7.818 & 24.0 & 0.050 & 0.036 \\
\hline 14 & 7.660 & 24.0 & 0.030 & 0.016 \\
\hline 15 & 7.625 & 25.0 & 0.030 & 0.014 \\
\hline Mean & 7.697 & 23.1 & 0.044 & 0.032 \\
\hline$\pm \mathrm{SD}$ & \pm 0.092 & \pm 1.2 & \pm 0.043 & \pm 0.043 \\
\hline
\end{tabular}

\section{DISCUSSION}

Temperature coefficient. Generally, the electromotive force (EMF) of the $\mathrm{pH}$ calomel electrode assembly, $E$, is expressed by

$$
E=E^{\circ}+\alpha \mathrm{pH},
$$

where, $E^{\circ}$ is the standard potential $(\mathrm{mV})$, and $\alpha$ the sensitivity of electrode (slope) expressed in $-\mathrm{mV}$ per $\mathrm{pH}$. By differentiating Eq. (3) with respect to temperature $(t)$, one can derive

$$
\frac{d E}{d t}=\frac{d E^{\circ}}{d t}+\mathrm{pH} \frac{d \alpha}{d t}+\alpha \frac{d \mathrm{pH}}{d t} .
$$

$$
\text { (I) (II) (III) }
$$

Since (I) and (II) are considered to be particular constant values for the electrode system employed, they are combined and expressed as $d E^{*} / d t$.

Thus,

$$
\frac{d E^{*}}{d t} \equiv \frac{d E^{\circ}}{d t}+\mathrm{pH} \frac{d \alpha}{d t} .
$$

The value of $d E^{*} / d t$ for the Sb-microelectrode was determined by testing 2 solutions: i.e., (a) Tris buffer and (b) RB solution. As is shown in Fig. 2 and Table 2, the average of measured values of $d E / d t$ for Tris and $\mathrm{RB}$ by $\mathrm{Sb}$-microelectrode, was -0.06 and $-1.18 \mathrm{mV} /{ }^{\circ} \mathrm{C}$, respectively. Using Eqs. (4) and (5), one can calculate 
the values of $d E^{*} / d t$ for the Sb-microelectrode in Tris and RB solution, as (see APPENDIX)

$$
\begin{aligned}
& \left(\frac{d E^{*}}{d t}\right)_{\mathrm{Sb} \cdot \operatorname{Tris}}=\frac{d E}{d t}-\alpha \frac{d \mathrm{pH}}{d t}=-0.06-1.63=-1.69 \mathrm{mV} /{ }^{\circ} \mathrm{C}, \\
& \left(\frac{d E^{*}}{d t}\right)_{\mathrm{Sb} \cdot \mathrm{R} \mathrm{B}}=\frac{d E}{d t}-\alpha \frac{d \mathrm{pH}}{d t}=-1.18-0.15=-1.33 \mathrm{mV} /{ }^{\circ} \mathrm{C} .
\end{aligned}
$$

The difference in these two values, unless due to that of liquid junction potential, would probably depend on the error concerning $d \alpha / d t$ (the component (II)), because the $\mathrm{Sb}$-microelectrode which behaves non-ideally might react differently to Tris or RB even during the calibration stage where all the physicochemical properties (ionic strength, osmolality, etc.) are maintained identical in both solutions. Since we were unable to decide which was more suitable for the value of $\left(d E^{*} / d t\right)_{\mathrm{Sb}}$ in general, we regarded $-1.51 \mathrm{mV} /{ }^{\circ} \mathrm{C}$, the mean value of the two, as the real value of $d E^{*} / d t$ for the $\mathrm{Sb}$-microelectrode for the sake of convenience.

When the Sb-microelectrode is calibrated with Tris buffer, the calculation of Eqs. (4) and (5) yields

$$
\left(\frac{d E}{d t}\right)_{\mathrm{Sb} \cdot \operatorname{Tris}}=-1.69+1.63=-0.06 \mathrm{mV} /{ }^{\circ} \mathrm{C} .
$$

It is noted that the two components, $d E^{*} / d t$ and $\alpha \cdot d \mathrm{pH} / d t$ of the temperature coefficient for the Sb-microelectrode cancell each other in Tris buffer solution. This suggests that changes of temperature may have little effect on the EMF of the Sb-microelectrode when calibrated with Tris buffer solution.

The temperature coefficient in terms of $d \alpha / d t$ for the Sb-microelectrode was shown to be $-0.40 \mathrm{mV} / \mathrm{pH} /{ }^{\circ} \mathrm{C}$, as indicated in the regression equation in Fig. 3 . It is about twice as great as the theoretical value of thermodynamic response, $0.20 \mathrm{mV} / \mathrm{pH} /{ }^{\circ} \mathrm{C}$, as given by the dotted line in Fig. 3. The reason for this difference is not clear in detail, but it might be related to the fact that the reactions underlying the antimony electrode system are not so simple, because of the complicated participation of several components including metal oxides, oxyanions and oxycations (see Fig. 7 below).

Table 5 summarizes all the data stated above which concerns the temperature coefficient for both the glass and Sb-microelectrode measured in Tris and RB solutions.

From a practical point of view, the temperature coefficient of $\Delta \mathrm{pH}_{\mathrm{Sb} \text {-G1ass }}$ would become simpler as far as we could use $0.00183 \mathrm{pH} /{ }^{\circ} \mathrm{C}$ as an empirical value (Fig. 4). In other words, it may be stated that in practice the Sb-microelectrode, calibrated with Tris buffer, should be corrected for the temperature effect by means of Eq. (2), as was described previously.

Oxygen effect. In the antimony-antimony oxide electrode, the EMF is probably developed by an oxidation-reduction reaction involving antimony and the 
Table 5. Temperature coefficients for the glass and $\mathrm{Sb}$ microelectrode in Tris and RB solutions.

\begin{tabular}{cccccc}
\hline & & \multicolumn{4}{c}{ Temperature coefficient } \\
\cline { 3 - 6 } & & $\begin{array}{c}d E / d t \\
\left(\mathrm{mV} /{ }^{\circ} \mathrm{C}\right)\end{array}$ & $\begin{array}{c}\alpha \cdot d \mathrm{pH} / d t \\
\left(\mathrm{mV} /{ }^{\circ} \mathrm{C}\right)\end{array}$ & $\begin{array}{c}d E^{*} / d t \\
\left(\mathrm{mV} /{ }^{\circ} \mathrm{C}\right)\end{array}$ & $\begin{array}{c}d \alpha / d t \\
\left(-\mathrm{mV} / \mathrm{pH} /{ }^{\circ} \mathrm{C}\right)\end{array}$ \\
\hline Glass elect. & Tris & 1.05 & 1.63 & -0.58 & 0.20 \\
Sb-elect. & RB & -0.43 & 0.15 & & 0.40 \\
& Tris & -0.06 & 1.63 & -1.69 & -1.51 \\
\hline
\end{tabular}

The temperature coefficient of the electrode system is shown by the equation. The terms involved in the equation are given in the individual columns of the table. For explanation, see text.

${ }^{\dagger}$ Temperature coefficient $=\frac{d E}{d t}=\frac{d E^{\circ}}{d t}+\mathrm{pH} \frac{d \alpha}{d t}+\alpha \frac{d \mathrm{pH}}{d t}=\frac{d E^{*}}{d t}+\alpha \frac{d \mathrm{pH}}{d t}$.

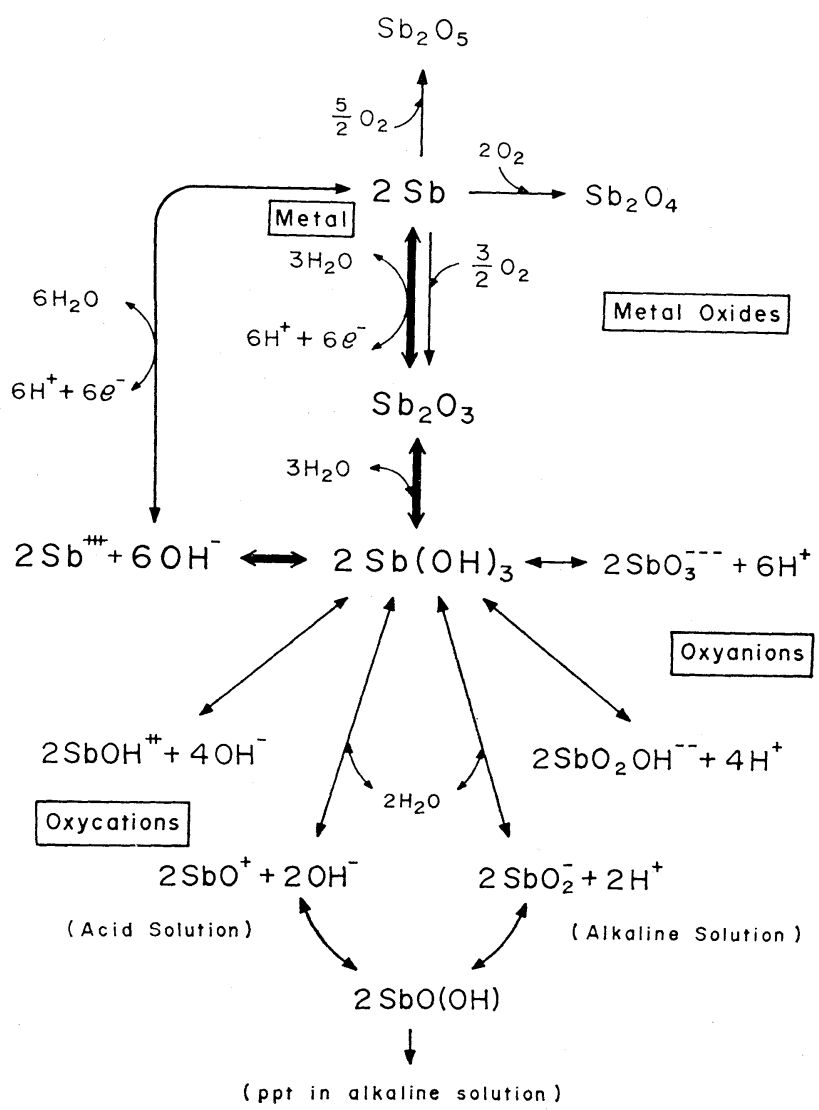

Fig. 7. Reactions of antimony-antimony oxide electrode system. 
thin layer of antimonous oxide (commonly antimony trioxide, $\mathrm{Sb}_{2} \mathrm{O}_{3}$ ) that is usually present on the surface of the metal. The whole reaction which will occur in the system is summarized in Fig. 7, illustrating that conditions of metal oxides have various influences on the behavior of the electrode. The main electrode reaction is indicated by thick lines. An additional reaction involving oxygen may also participate in this reaction. Simply, $\mathrm{Sb}_{2} \mathrm{O}_{3}$ is produced from $2 \mathrm{Sb}$ and $3 / 2\left(\mathrm{O}_{2}\right)$, by the reaction

$$
2 \mathrm{Sb}+\frac{3}{2} \mathrm{O}_{2} \longrightarrow \mathrm{Sb}_{2} \mathrm{O}_{3}
$$

This process itself does not directly generate electric current or potential, because there is no electron flow in this process. However, it certainly affects the rate of formation of $\mathrm{Sb}_{2} \mathrm{O}_{3}$ which is associated with a current generating system,

$$
2 \mathrm{Sb}(\mathrm{s})+3 \mathrm{H}_{2} \mathrm{O} \rightleftharpoons \mathrm{Sb}_{2} \mathrm{O}_{3}(\mathrm{~s})+6 \mathrm{H}^{+}+6 e^{-} \text {. }
$$

Therefore, some potential change, if any, would take place as a result of the interfering effect of reaction (6) on the main reaction (Eq. 7).

One can derive the change of EMF in the Sb-electrode, $\Delta E_{\mathrm{Sb}}$, as (see APPENDIX)

$$
\begin{aligned}
& \left.\Delta E_{\mathrm{Sb}}=-59.2 \nu(\Delta \mathrm{pH})+14.8 \nu r \Delta \log \left(P_{\mathrm{O}_{2}}\right) \quad \text { (at } 25^{\circ} \mathrm{C}\right) . \\
& (\mathrm{mV})
\end{aligned}
$$

If the $\mathrm{Sb}$-electrode behaved as a true oxygen electrode, then both $\nu$ and $r$ would become unity and $d E / d \log \left(P_{\mathrm{O}_{2}}\right)$ would be $14.8 \mathrm{mV}$ per tenfold change of $P_{\mathrm{O}_{2}}$ in $\mathrm{mmHg}$, under conditions of constant $\mathrm{pH}$ (IVES, 1961). In our experiment, $d E / d \log$ $\left(P_{\mathrm{O}_{2}}\right)$ was $11.7 \pm 0.42 \mathrm{mV}$ (at $25^{\circ} \mathrm{C}, n=13$, mean $\pm \mathrm{SEM}$ ) (see Table 3 ) at the constant $\mathrm{pH}$ of $7.7 \pm 0.1$. Our electrodes had a mean slope of $-55.3 \mathrm{mV} / \mathrm{pH}$ (see Fig. 3), which indicated that $\nu$ was $0.93(=55.3 / 59.2)$, and hence, $r$ was $0.85(=11.7 /$ $(14.8 \times 0.93))$. Thus, in view of various errors included, our result was essentially in agreement with the theoretical value and the data $\left(14.7 \mathrm{mV}\right.$ at $\left.25^{\circ} \mathrm{C}\right)$ of KAUKO and KNAPPSBERG (1939), but different from the data of MALNIC and his coworkers (1972) and PuschetT and Zurbach (1974), who did not find a significant effect of $P_{\mathrm{O}_{2}}$ on the EMF of the Sb-microelectrode, and of QUEHENBERGER (1977), who reported a higher value of $58.5 \mathrm{mV}$ per tenfold change of $P_{\mathrm{O}_{2}}$. The reason for the discrepancy between our findings and data of these workers remains unclear. Even the predictions that the higher oxygen tension would form the higher antimony oxides (EL WAKKAD, 1950) and that the standard potential would be affected by oxygen tension (TourKy and Moussa, 1948) are not yet clearly defined.

However, it can be stated from our data that the $\mathrm{pH}$ measurement in the range of 50 to $100 \mathrm{mmHg}$ of $P_{\mathrm{O}_{2}}, \Delta E$ is only $\pm 0.07 \mathrm{mV}$ per $1 \mathrm{mmHg}$ change of $P_{\mathrm{O}_{2}}$. Since it corresponds to \pm 0.0012 of $\Delta \mathrm{pH}$, the effect of $P_{\mathrm{O}_{2}}$ on the Sb-microelectrode is relatively small in the physiological range where no large change of $P_{\mathrm{O}_{2}}$ is produced.

Measurement of blood $\mathrm{pH}$. As a biological application of the Sb-microelectrode, blood $\mathrm{pH}$ of bullfrog was determined at various room temperatures. $\mathrm{pH}$ 
values tended to decrease with a rise of temperature with both Sb-micro and glass electrodes. This temperature effect was larger in the Sb-microelectrode than in the glass electrode, unless the correction for the change of temperature coefficient was made. By correction for the temperature effect by means of Eq. (2), the value of $\Delta \mathrm{pH}_{\mathrm{Sb}-\mathrm{Glass}}$ was reduced from $0.044 \pm 0.043$ (SD) to $0.032 \pm 0.043$ (see Table 4).

Previously, Yoshimura (1936) reported that the $\mathrm{pH}$ value measured by means of the antimony electrode differed markedly from that determined by the hydrogen gas electrode or the glass electrode. His value for $\Delta \mathrm{pH}_{\mathrm{Sb} \text {-G1ass }}$ ranged from -0.007 to -0.184 in goat plasma and $\Delta \mathrm{pH}_{\mathrm{Sb}-\mathrm{H}_{2}}$ from 0.293 to 0.466 in horse plasma. Thus his conclusion was that the antimony electrode could not be applied to the determination of plasma $\mathrm{pH}$. The reason for the discrepancy between our findings and his data is not clear, but would probably be related to the following facts: (1) Difference of electrode. His electrode was a plated and stick-type antimony electrode, whereas ours was a microelectrode with highly purified antimony metal $(99.999 \%)$ mounted in a glass capillary, only the tip being made $\mathrm{pH}$ sensitive and having the advantages of suffering a lesser degree of stirring effect and minor heterogeneity of the metal surface. (2) Difference of calibration solution. Yoshimura used Mc Ilvaine buffer and Sörensen phosphate buffer for calibration, which have sizable and varied effects on the EMF of the Sb-electrode, whereas we used Tris buffer, which has the least effect (MATsumura et al., 1980). (3) Difference of electrometry. We used electrode cables with highly insulating material (teflon), connected to an electrometer with high input impedance of more than $10^{14} \Omega$. Though Yoshimura used an excellent vacuum tube (Toshiba UX-54) whose grid current was of the order of $10^{-14} \mathrm{~A}, 40$ years ago was not a favorable time for obtaining a better insulating material for the connecting cable and electronic apparatus.

In all likelihood, therefore, we may conclude that a more or less fair measurement of $\mathrm{pH}$ of biological fluid would be possible by the Sb-microelectrode in so far as the temperature effect is taken into account and calibration is properly done.

\section{APPENDIX}

\section{Temperature coefficient}

The temperature coefficient of the EMF of the $\mathrm{pH}$ calomel electrode system can be expressed as

$$
\frac{d E}{d t}=\frac{d E^{*}}{d t}+\alpha \frac{d \mathrm{pH}}{d t}
$$

By electrometry of the total electrode system, only the value for $d E / d t$ can be measured. For the determination of individual components of the temperature coefficient, our approach was by means of the following steps. 
In the first step, $d E^{*} / d t$ can be assessed by comparing the theoretical and actually measured temperature coefficients of a well-characterized electrode system, such as a glass $\mathrm{pH}$ electrode with internal and external reference electrodes of calomel half-cells. In Tris buffer, for example, the theoretical temperature coefficient could be approximated (BATES, 1973), as

$$
\begin{aligned}
\frac{d \mathrm{pH}}{d t} & \simeq-\frac{d \log K_{\mathrm{w}}}{d t}+\frac{d \log K_{\mathrm{b}}}{d t} \\
& \fallingdotseq-0.0330+0.0054 \\
& \fallingdotseq-0.0276 \mathrm{pH} /{ }^{\circ} \mathrm{C}\left(\text { at } 25^{\circ} \mathrm{C}\right)
\end{aligned}
$$

where $K_{\mathrm{w}}$ and $K_{\mathrm{b}}$ are the ionic product of water and the dissociation constant of organic base, Tris-(hydroxymethyl)-aminomethane $\mathrm{HCl}$, respectively. Converting the unit of $\mathrm{pH} /{ }^{\circ} \mathrm{C}$ into $\mathrm{mV} /{ }^{\circ} \mathrm{C}$ and assuming $\alpha$ for the glass electrode to be $-59.2 \mathrm{mV} / \mathrm{pH}$, one can obtain the theoretical value for $\alpha \cdot d \mathrm{pH} / d t$ as $1.63 \mathrm{mV} /{ }^{\circ} \mathrm{C}$. The measured value for Tris buffer, $d E / d t$, was, on average, $1.05 \mathrm{mV} /{ }^{\circ} \mathrm{C}$, as is shown in Table 2. From Eq. (9), $d E^{*} / d t$ for the glass electrode is calculated to be $-0.58(=1.05-1.63) \mathrm{mV} /{ }^{\circ} \mathrm{C}$. Thus, for the glass electrode system, one can use the empirical formula

$$
\left(\frac{d E}{d t}\right)_{\text {G1ass }}=-0.58+\alpha \cdot \frac{d \mathrm{pH}}{d t} .
$$

In the second step, the temperature coefficient which may be theoretical for Ringer bicarbonate solution (RB) is calculated from Eq. (11) for the glass electrode. As the measured value of $d E / d t$ for $\mathrm{RB}$ was $-0.43 \mathrm{mV} /{ }^{\circ} \mathrm{C}$ (see Table 2), the value of $\alpha \cdot \mathrm{dpH} / d t$ for $\mathrm{RB}$ is estimated to be $0.15(=-0.43-(-0.58)) \mathrm{mV} /{ }^{\circ} \mathrm{C}$.

\section{Oxygen effect}

In the presence of oxygen, reactions (6) and (7) proceed, generating an electron flow across the solid and liquid interfaces. If extra oxygen was added to main reaction (7), then the following electrochemical process might be expected:

$$
\frac{1-r}{n} \mathrm{Sb}(\mathrm{s})+\frac{1}{2} \mathrm{H}_{2} \mathrm{O}(\mathrm{l})-\frac{r}{4} \mathrm{O}_{2}(\mathrm{l}) \rightleftharpoons \frac{1-r}{2 n} \mathrm{Sb}_{2} \mathrm{O}_{n}(\mathrm{~s})+\mathrm{H}^{+}+e^{-},
$$

where $r$ is the molar ratio of participating gaseous oxygen with respect to the unit occurrence of the main redox reaction; $n$ is the oxidation number of antimony metal, such as 3 (trioxide), 4 (tetroxide) and 5 (pentoxide); (s) and (l) indicate solid and liquid phase, respectively. In the above equation, if oxygen is not participating in the system, $r$ is zero. Additionally, if $n$ is 3, as is usually seen, then Eq. (12) is reduced to Eq. (7), which is independent of oxygen tension.

In diluted aqueous media, the EMF of this system would be practically a function of hydrogen ion concentration, $\left[\mathrm{H}^{+}\right]$:

$$
E_{\mathrm{Sb}}=E_{\mathrm{Sb}}^{\circ}+\frac{\nu R T}{F} \ln \left[\mathrm{H}^{+}\right],
$$


where $\nu$ is an empirical constant (dimensionless) which takes into account the non-ideal behavior of the Sb-microelectrode. For a more precise reaction, as described in Eq. (12), we have

$$
E_{\mathrm{Sb}}=\overline{E_{\mathrm{Sb}}^{\circ}}-\frac{\nu R T}{F} \ln \frac{[\mathrm{Sb}]^{(1-r) / n}\left[\mathrm{H}_{2} \mathrm{O}\right]^{(1 / 2)}}{\left[\mathrm{H}^{+}\right]\left[\mathrm{Sb}_{2} \mathrm{O}_{n}\right]^{(1-r / 2 n)}\left[\mathrm{O}_{2}\right]^{(r / 4)}},
$$

where $\overline{E_{\mathrm{Sb}}^{\circ}}$ is the standard potential of the system, in which oxygen is involved. Since the partial molal volume of metal $\mathrm{Sb}$ is unity, the equation concerning the EMF (mV) of the Sb-microelectrode is written by the following expression:

$$
\begin{aligned}
& E_{\mathrm{Sb}}=\overline{E_{\mathrm{Sb}}^{\circ}}-0.1983 \nu T\left[\mathrm{pH}-\frac{r}{4} \log \left(\mathrm{O}_{2}\right)-\frac{1-r}{2 n} \log \left(\mathrm{Sb}_{2} \mathrm{O}_{n}\right)+\frac{1}{2} \log \left(\mathrm{H}_{2} \mathrm{O}\right)\right] . \\
& (\mathrm{mV})
\end{aligned}
$$

Further, Henry's gas law states

$$
\left(\mathrm{O}_{2}\right)=\beta_{\mathrm{O}_{2}}\left(P_{\mathrm{O}_{2}}\right) \text {, }
$$

where, $\beta_{\mathrm{O}_{2}}$ stands for the absorption coefficient of $\mathrm{O}_{2}$, and $P_{\mathrm{O}_{2}}$ denotes the partial pressure of oxygen in mmHg. Substituting Eq. (16) into Eq. (15), and assuming that the concentration of solid $\mathrm{Sb}_{2} \mathrm{O}_{n}$ and liquid $\mathrm{H}_{2} \mathrm{O}$ remains constant in the reaction, one can derive the change of $\mathrm{EMF}$ in the $\mathrm{Sb}$-electrode, $\Delta E_{\mathrm{Sb}}$, as

$$
\begin{aligned}
& \Delta E_{\mathrm{Sb}}=-59.2 \nu(\Delta \mathrm{pH})+14.8 \nu r \Delta \log \left(P_{\mathrm{O}_{2}}\right) \quad\left(\text { at } 25^{\circ} \mathrm{C}\right) . \\
& (\mathrm{mV})
\end{aligned}
$$

The authors are grateful to Miss Yaeko Nagashima for typewriting this manuscript and to Mr. Kazutomo Kachi for programming the data computation. This research was supported by the Grant-in-Aid for Scientific Research from the Ministry of Education, Science and Culture of Japan (248101, 1978), to which the authors' thanks is due.

\section{REFERENCES}

BAtes, R. G. (1973) Determination of pH, Theory and Practice, John Wiley and Sons, New York, pp. 105-133.

EL WAKKAD, S. E. S. (1950) The electrochemical behaviour of the antimony electrode. $J$. Chem. Soc. (Perkin I), 54: 2894-2896.

Fujimoto, M., Matsumura, Y., and Satake, N. (1980) General properties of antimony microelectrode in comparison with glass microelectrode for the $\mathrm{pH}$ measurement. Jpn.J. Physiol., 30: 491-508.

Green, R. and Giebisch, G. (1974) Some problems with the antimony microelectrode. In: Ion Selective Microelectrodes, ed. by Berman, H. J. and Herbert, N. S. Plenum Press, New York, pp. 43-53.

GreEN, R. and Grebisch, G. (1975) Ionic requirements of proximal tubular sodium transport. II. Hydrogen ion. Am. J. Physiol., 229: 1216-1226.

Ives, D. J. G. (1961) Oxide, oxygen, and sulfide electrodes. In: Reference Electrodes, Theory and Practice, ed. by Ives, D. J. G. and JANZ, G. J., Academic Press, Inc., New York, pp. 322392.

KAUKo, Y. and KNAPPsBerg, L. (1939) Über die Antimonelektrode. Z. Elektrochem., 45: 760- 
769.

Karlmark, B. and Danielson, B. G. (1974) Titratable acid, $P_{\mathrm{CO}_{2}}$, bicarbonate and ammonium ions along the rat proximal tubule. Acta Physiol. Scand., 91: 243-258.

Kotera, K., Matsumura, Y., and Fujimoto, M. (1977) Coupling of H ion to other electrolyte transport across the tubular epithelium of bullfrog kidneys. Proc. XXVIIth Int. Union Physiol. Sci. (Paris), 13: 405.

Malnic, G., De Mello Aires, M., and Giebisch, G. (1972) Micropuncture study of renal tubular hydrogen ion transport in the rat. Am. J. Physiol., 222: 147-158.

Matsumura, Y., Satake, N., and Fujimoto, M. (1980) Physicochemical characteristics of antimony microelectrode with special reference to selection of standard buffers. Jpn. J. Physiol., 30: 509-528.

Perley, G. A. (1939) Characteristics of the antimony electrode. Ind. Eng. Chem. Anal. Ed., 11: 319-322.

PuschetT, J. B. and ZurbaCH, P. E. (1974) Re-evaluation of microelectrode methodology for the in vitro determination of $\mathrm{pH}$ and bicarbonate concentration. Kidney Int., 6: 81-91.

QUEHENBERGER, P. (1977) The influence of carbon dioxide, bicarbonate and other buffers on the potential of antimony microelectrodes. Pflügers Arch., 368: 141-147.

Satake, N., Matsumura, Y., and Fujimoto, M. (1980) Protein effect on the antimony microelectrode in application to biological fluid. Jpn. J. Physiol., 30: 689-700.

Sohtell, M. and Karlmark, B. (1976) Instruments and techniques: In vivo micropuncture $P_{\mathrm{CO}_{2}}$ measurements. Pflügers Arch., 363: 179-180.

Stock, J. T., Purdy, W. C., and Garcia, L. M. (1958) The antimony-antimony oxide electrode. Chem. Rev., 58: 611-626.

Tourky, A. R. and Moussa, A. A. (1948) Studies on some metal electrodes. Part III. Does the antimony electrode behave simply as a metal-metal oxide electrode in air? J. Chem. Soc. (Perkin I), 752-756.

Vieira, F. L. and MALNiC, G. (1968) Hydrogen ion secretion by rat renal cortical tubules as studied by an antimony microelectrode. Am. J. Physiol., 214: 710-718.

Yoshimura, H. (1936) On the applicability of antimony electrode to the determination of hydrogen ion concentration, especially on that of the blood. Jpn.J. Med. Sci. (3), 4: 131-141. 